\title{
COMMENTS
}

\section{HAZELWOOD SCHOOL DISTRICT AND THE ROLE OF FIRST AMENDMENT INSTITUTIONS}

\author{
BRUCE C. HAFEN*
}

The Supreme Court's five-to-three decision in Hazelwood School District $v$. Kuhlmeier, ${ }^{1}$ which authorizes educators to supervise the content of an official high school newspaper, is probably the most significant free speech case involving public school students since tlie Court decided Tinker v. Des Moines Independent Community School District ${ }^{2}$ almost twenty years ago. Hazelwood is interesting not only because it marks the Court's first application of first amendment principles to public school newspapers, but because the case creates a category of student speech ${ }^{3}$ to which Tinker no longer applies: "school-sponsored expressive activities." I wish to suggest that, rather tlian weakening the Court's commitment to the constitutional rights of students, Hazelwood seeks to strengthen students' fundamental interest in the underlying principles of free expression: the right to develop their own educated capacity for selfexpression. The Court now seems to recognize that schools as well as courts can advance and protect the values of the first amendment.

This decision reinforcing the institutional authority of schools also reflects the Court's developing perspective on the general role of first amendment institutions. 5 The Hazelwood Court rejected students'

* Dean and Professor of Law, Brigham Young University Law School. The author wishes to thank Rex E. Lee for his comments on an earlier draft of this Comment.

1. 108 S. Ct. 562, 571 (1988).

2. 393 U.S. 503 (1969).

3. For an observation on Hazelwood's method of categorization, see infra notes $63-65$ and accompanying text.

4. Hazelwood, 108 S. Ct. at 571.

5. I have elsewhere more fully described the role of "mediating institutions," which can nurture constitutional values by enabling personal development and providing a buffer against state intrusion. See Hafen, Developing Student Expression Through Institutional Authority: Public Schools as Mediating Structures, 48 OHо ST. L.J. 663 (1987). Among the most significant of these institutions are what Tocqueville called the "intellectual and moral associations," those institutional carriers of meaning that can advance the underlying values of the first amendment in the lives of individuals. See id. at 696-99. In this Comment, I call these associations "first amendment institutions," reflecting my premise that the first amendment protects "not only individual religious liberty, but the institutional liberty of churches; not only personal academic freedom, but the institutional 
claims to individual freedom of expression in favor of educators' broad authority to define and supervise the educational mission of public schools both in and out of the classroom. Clarifying doubts about the breadth of its rationale in a 1986 student assembly speech case ${ }^{6}$ and resolving some of the uncertainty arising from its fractured opinions in a 1982 library book banning case, ${ }^{7}$ the Court strengthened schools' right to institutional discretion whenever educational activities are mvolved. $\mathrm{Ha}$ zelwood's deferential approach in an area where limitations on expression have becoine highly suspect--newspapers-reflects the Court's emerging recognition of the affirmative role of certaim intermediate institutions in first ainendinent theory.

The Court's new emphasis on first amendment institutions seems to arise not merely from the speech-related associational interests of individual members in a group, but also from an understanding that first amendinent institutions $q u a$ institutions can sustain conditions that nourish such values as those associated with rehion and expression. ${ }^{8}$ Significantly, this understanding follows a turbulent generation in which critics opposed to all forms of institutional authority expressed a profound anti-institutional skepticism in the name of individual rights. ${ }^{9}$ But not all institutional influences undermine individual rights. Indeed, as the Court is beginning to note, personal rights may take ongoing sustenance froin certain forms of institutional nurturing.

Two examples from the Supreme Court's recent jurisprudence of first amendment institutions illustrate this broad context for Hazelwood. Only last year in Corporation of the Presiding Bishop v. Amos, ${ }^{10}$ the Court unanimously rejected an establishment clause challenge to a federal statute that granted religious institutions the right to discriminate in favor of

liberty of schools and colleges; not only individual freedom of speech, but the associational or institutional freedom of groups and newspapers." Id. at 698.

I wrote the Ohio State Law Journal article in anticipation of the Supreme Court's review of the Eighth Circuit's deeision in Kuhlmeier v. Hazelwood School Dist., 795 F.2d 1368 (8th Cir. 1986), rev'd, 108 S. Ct. 562 (1988). That article's theory of public schools as first amendment institutions provides some of the conceptual framevrork for this Comment.

6. Bethel School Dist. No. 403 v. Fraser, 478 U.S. 675 (1986); see infra notes $40-48$ and accompanying text.

7. Board of Educ. v. Pico, 457 U.S. 853 (1982); see infra notes 32-39 and accompanying text.

8. Justice Brennan has described a church or religious community as "an organic entity not reduciblc to a mere aggregation of individuals." Corporation of the Presiding Bishop v. Amos, 107 S. Ct. 2862, 2871 (1987) (Brennan, J., concurring). Compare the more traditional right of association cases, which emphasize the individual's right to associate with others rather than the institutional rights of organic entities. E.g., Board of Directors of Rotary Int'l v. Rotary Club of Duarte, 107 S. Ct. 1940 (1987); Roberts v. United States Jaycees, 468 U.S. 609 (1984); NAACP v. Alabama, 357 U.S. 449 (1958).

9. The student rights movement exemplifies this era. See Hafen, supra note 5 , at $677-81$.

10. 107 S. Ct. at 2862 . 
their own members when making employment decisions for nonprofit activities. ${ }^{11}$ The statute had a valid secular purpose in that it reduced governmental interference "with the ability of rehgious organizations to define and carry out their religious missions." 12 Underscoring the connection between a religious organization's institutional autonomy and its role in advancing the first amendment interests of its individual members, Justice Brennan's concurring opinion observed that "[s]olicitude for a church's ability to [engage in its own self-definition] reflects the idea that furtherance of the autonomy of religious organizations often furthers individual religious freedom as well."13

Similarly, a less-noticed unanimous opmion during the Court's 1985 Term, Regents of the University of Michigan v. Ewing, ${ }^{14}$ added measurable vitality to the notion of institutional academic freedom for colleges and universities. ${ }^{15}$ Upholding a university's wide latitude in judging its students' academic fitness for continued enrollment, Justice Stevens explained that "[a]cademic freedom thrives not only on the independent and uninhibited exchange of ideas among teachers and students, but also, and somewhat inconsistently, on autonomous decisionmaking by the academy itself." 16

These two cases and Hazelwood contrast sharply with what seemed during the 1960 s and 1970 s to be a long-term and probably irreversible trend: the expansion of individual rights in derogation of all forms of institutional authority, including the discretion of schools and other public and private agencies involved with children.17 Because Hazelwood reflects the Court's new emphasis on first amendment institutions, it deserves attention even beyond its impact on the Tinker standards.

Part I of this Comment summarizes Tinker and the Court's other pre-1988 student expression cases. Part II describes the Court's holding and rationale in Hazelwood. In part III, the Comment responds to the prevailing scholarly view (echoed in the Hazelwood dissent) that the first amendment should limit schools' discretion; the Comment puts into historical context the individuahstic assumptions behind that view and con-

11. Id.

12. Id. at 2868 .

13. Id. at 2871-72 (Brennan, J., concurring).

14. 474 U.S. 214 (1985).

15. Justice Frankfurter's concurring opinion in Sweezy v. New Hampshire, 354 U.S. 234, 26263 (1957), first noted the possibility of such an institutional right, but this right did not provide the rationale for a holding until Justice Powell's opinion in University of Cal. Regents v. Bakke, 438 U.S. 265, 311-15 (1978). See Hafen, supra note 5, at 712-18.

16. Ewing, 474 U.S. at 226 n.12 (citations omitted).

17. I have summarized applications of this trend to policies involving children in Hafen, $E x$ ploring Test Cases in Child Advocacy, 100 HARv. L. REV. 435 (1986) (reviewing R. MNOokIN, IN the Interest of Children: Advocacy, Law Reform, and Public Policy (1985)). 
cludes that increased autonomy for first amendment institutions can advance our long-term interest in sustaining individual liberty.

\section{The Student Expression Cases}

The Supreme Court first recognized the freedom of expression interests of public scliool students in 1943, when, in West Virginia State Board of Education v. Barnette, it held that a coinpulsory flag salute exercise was an unconstitutional coercion of belief. ${ }^{18}$ The Court first protected actual student expression in 1969, when it upheld in Tinker the right of students to protest the government's involveinent in the Vietnain War by wearing black armbands on school grounds (including classrooins). ${ }^{19}$ Significantly, the Court decided Tinker at the height of the late 1960s student protest inoveinents, when that era's inounting national tensions virtually required an affirmative answer to the question whether the first ainendment protects any student expression at all. By legitimizing the idea that student speech deserves some protection, the Court increased the likelihood that student complaints would elicit constructive responses within existing institutional channels. ${ }^{20}$

The Tinker facts inade that case an ideal opportunity for recognizing students' free speech interests: the students wore their armbands peacefully under their parents' direction, their symbolic expression addressed the most important political issue of the day, and their statement was not a "group demonstration[ ],"21 but "personal intercommumication among the students"22 akin to a conversation that neither "intrude[d] upon the work of the schools"23 nor implied any official endorsennent. These facts align Tinker not only witl Barnette, the flag salute case, ${ }^{24}$ but also with the school prayer cases: just as the first ainendment's commitinent to freedom of the mind forbids a school from coercing the adoption of a personal belief, it also forbids a school from punishing the purely personal expression of a belief. Thus, drawing upon establishinent clause doctrine, school officials should not prevent a student froin saying a personal, silent prayer before an exainination, lest they coerce her belief by apparently endorsing the view that prayer is wrong. Yet they should not allow that same student to lead her class in group prayer, lest their apparent endorsement of prayer have a coercive

\footnotetext{
18. 319 U.S. 624,642 (1943).

19. Tinker v. Des Moines Indep. Community School Dist., 393 U.S. 503, 514 (1969).

20. Hafen, supra note 5 , at 691 .

21. Tinker, 393 U.S. at 508.

22. Id. at 512 .

23. Id. at 508.

24. See supra note 18 and accompanying text.
} 
effect on the beliefs of other students. ${ }^{25}$ Hazelwood now draws a similar distinction between a student's private speech, which remains eligible for protection under Tinker, and her expression through official school channels, which Tinker no longer protects. These cases reason not from the premise that a school is a public forum for rational adults, but from the opposite premise that young students must have unusual protection against coercive influence on their behiefs precisely because they lack the rational capacity of adults. ${ }^{26}$

In part because of some expansive language in Justice Fortas's majority opinion, ${ }^{27}$ however, courts and commentators have long given Tinker much broader readings than this interpretation suggests. Many have concluded that a high school really is a public forum in which the adult "marketplace of ideas" concept holds full sway. This perspective has condemned attempts to limit student expression, characterizing them as a forbidden form of censorship. Indeed, the dommant assumption in most school speech cases has been that Tinker established a constitutional presumption agamst limitations on student expression-rebuttable only upon a showing of material (usually physical) disruption of sclioolwork or clear invasions of the rights of others. Until Hazelwood the presence of education-related interests in extracurricular affairs typically did not overcome this presumption.

For example, in 1986 the Ninth Circuit applied Tinker to protect a vulgar student-assembly speech, ${ }^{28}$ because the evidence showed that the speech caused no real "disruption" in either the assembly or classrooms. And in Hazelwood, the Eighth Circuit applied Tinker to prevent school officials from removing student newspaper stories, stating that no such administrative supervision was permissible unless the stories threatened a disruption or a tortious imvasion of the rights of other persons. ${ }^{29}$ Most courts did allow some prior review of school-sponsored student publications, but with very limited deference to the judgments of school

25. See Wallace v. Jaffree, 472 U.S. 38, 61 n.51 (1985) (When a school acts to influence children in "matters sacred to the conscience[,] ... [t]he law of imitation operates, and non-conformity is not an outstanding characteristic of children.") (quoting McCollum v. Board of Educ., 333 U.S. 203, 227 (1948)).

26. See infra notes $85-86$ and accompanying text.

27. See Tinker, 393 U.S. at 506, 509, 513.

28. Fraser v. Bethel School Dist. No. 403, 755 F.2d 1356 (9th Cir. 1985), rev'd, 478 U.S. 675 (1986).

29. Kuhlmeier v. Hazelwood School Dist., 795 F.2d 1368 (8th Cir. 1986), rev'd, 108 S. Ct. 562 (1988). A few courts have more narrowly applied the "disruption" and "rights of others" standards. The Second Circuit, for example, found that the risk of psychological trauma sufficiently invaded students' rights to justify a school's prevention of the distribution of a questionnaire regarding sexual attitudes and practices. Trachtman v. Anker, 563 F.2d 512 (2d Cir. 1977), rev'g 426 F. Supp. 198 (S.D.N.Y. 1976), cert. denied, 435 U.S. 925 (1978). 
officials. ${ }^{30}$

Although after Tinker the Supreme Court contimued to address other issues raised in the public school context, ${ }^{31}$ the Court did not hear another school speech case until Board of Education v. Pico ${ }^{32}$ in 1982. Pico did not offer much clarification of Tinker, because the case mvolved a school board's attempt to remove library books rather than the suppression of any actual student expression. In addition, no majority opinion addressed the merits of the first amendment issues in the case. ${ }^{33}$ Even at that, Pico by no means suggested that the Court suspiciously vievs a school board's discretionary judgments on most educational matters. A three-Justice plurality found that students have a "right to receive information and ideas" 34 that prevents the arbitrary or suppressive removal of library books, but they still acknowledged a school board's right to remove books that the board finds "pervasively vulgar" or otherwise lacking in "educational suitability." 35 Those subjective limits go well beyond Tinker's concerns with disruption and harm. The plurality also acknowledged the board's unchallenged discretion im placimg initial orders for library books, ${ }^{36}$ its "absolute discretion" 37 im curricular matters, and its general "duty to inculcate community values." 38 Because the plurality viewed the library as outside the "compulsory environment of the classroom," 39 Pico's deference to school board judgments arguably anticipated Hazelwood's general deference in situations inıphicatimg educational judgments in or out of the classroom.

The Court decided its next student expression case, Bethel School District No. 403 v. Fraser, ${ }^{40}$ on the same day that the Eighth Circuit handed down its opinion in Hazelwood. ${ }^{41}$ By a seven-to-two inargin, the Supreme Court reversed the Eighth Circuit and upheld a school official's right to discipline a student for giving a vulgar campaigu speech in a student body elections assembly. This decision narked a potentially sig-

30. The split of authority prior to Hazelwood is summarized in Note, Administrative Regulation of the High School Press, 83 Mich. L. REv. 625 (1984).

31. See, e.g., New Jersey v. T.L.O., 469 U.S. 325 (1985) (fourth amendment search and seizure); Goss v. Lopez, 419 U.S. 565 (1975) (procedural due process).

32. 457 U.S. 853 (1982).

33. The Court upheld the Second Circuit's decision, which remanded the case for a determination of the school board's actual motivation in ordering removal of the library books. Id. at 875 .

34. Id. at 867 (quoting Stanley v. Georgia, 394 U.S. 557, 564 (1969)).

35. Id. at 871 .

36. Id.

37. Id. at 869 .

38. Id.

39. Id.

40. 478 U.S. 675 (1986).

41. 795 F.2d 1368 (8th Cir. 1986), rev'd, 108 S. Ct. 562 (1988). Both decisions were issued July $7,1986$. 
nificant departure from Tinker. The record in the case contained no finding that the speech caused substantial disruption, and no one claimed that the speech seriously invaded the rights of others. Moreover, Matthew Fraser's speech, like the Tinker children's armbands, involved highly protected political expression: this was a student elections ineeting. Notwithstanding these similarities to Tinker, however, the majority opinion painted the school's educational domain in broad strokes, even resurrecting the in loco parentis doctrime $\mathrm{e}^{42}$ to reaffirm the place of public schools in teaching basic values within and beyond the classroom: "The process of educating our youth for citizenship in public schools is not confined to books, the curriculum, and the civics class." 43

Fraser could be read more narrowly, however, because it dealt with vulgar and offensive (even if not obscene) expression directed toward ininors in a captive audience. Thus read, the case arguably added little to the Tinker-era standards; the Court had long since upheld greater limits on indecent materials heard or viewed by children under the age of majority. ${ }^{44}$ Indeed, most of the commentary on Fraser views the opinion in these terms. ${ }^{45}$ The dissent in Hazelwood also asserted that "Fraser faithfully applied Tinker," because Fraser sought to regulate the manner but not the content of the speech. ${ }^{46}$

Hazelwood now makes clear, however, that Fraser rested on a more substantial foundation than the vulgarity of the student speaker's language: "A school need not tolerate student speech that is inconsistent with its 'basic educational mission." "47 Seen froni the perspective of $\mathrm{Ha}$ zelwood, Fraser was an important transitional case that signaled the Court's willingness to read Tinker inore narrowly than many lower courts had read it. By 1986, the Court could perhaps see that broad interpretations of Tinker had, along with other factors, reduced schools' institutional authority in ways that undermined their educational effec-

42. Fraser, 478 U.S. at 683.

43. Id.

44. See, e.g., FCC v. Pacifica Found., 438 U.S. 726 (1978) (upholding FCC restrictions of indecent language on radio); Ginsberg v. New York, 390 U.S. 629 (1968) (upholding statute banning sales to minors of inagazines not considered obscene for adults).

45. See, e.g., Recent Development, The Right of Free Speech in Public Schools: Bethel v. Fraser, 16 J.L. \& Educ. 119 (1987); Case Note, Bethel School District No. 403 v. Fraser: The Supreme Court Supports School in Sanctioning Student for Sexual Innuendo in Speech, 33 LoY. L. REv. 516 (1987). Other coinmentary sees, and for the inost part takes issue with, the Court's broader reasoning. See, e.g., T. van Geel, The Courts and American Education Law 235-37 (1987); Note, Protecting a School's Interest in Value Inculcation to the Detriment of Students' Free Expression Rights: Bethel School District v. Fraser, 28 B.C.L. REv. 595, 612-24 (1987).

46. Hazelwood, $108 \mathrm{~S}$. Ct. at 575 (Brennan, J., dissenting).

47. Id. at 567 (White, J.) (quoting Fraser, 478 U.S. at 685). 
tiveness. ${ }^{48}$ Thus, Fraser revealed the Court's desire to shore up school authority-a desire that Hazelwood confirms with a concrete and relatively broad new rule.

\section{HAZELWOOD AND THE LIMITS OF TINKER}

Spectrum was the official school newspaper produced by students in a journalism class at Hazelwood High School, near St. Louis. The paper had a reputation for addressing controversial topics, but in May of 1983 the school principal found certain Spectrum stories on teenage pregnancy and divorce inappropriately sensitive and personal, and deleted the pages containing the stories. ${ }^{49}$ The student authors filed suit, claiming infringement of their first amendment rights, and eventually won on appeal to the Eighth Circuit. ${ }^{50}$ The court held that Spectrum was a public forum ${ }^{51}$ and applied the standards established in Tinker. Because the court of appeals found no factual justification for the principal to forecast either a disruption or possible tort liability, it saw no basis for overcoming the Tinker presumptions favoring student speecli. ${ }^{52}$

In an opinion by Justice White, the Supreine Court reversed, finding that the school had not designated the paper a public forum ${ }^{53}$ and liold-

48. Hafen, supra note 5 , at 692 .

49. Hazelwood, $108 \mathrm{~S}$. Ct. at 565-66. The two deleted pages also contained other articles that "were deleted only because they appeared on the same page as the objectionable articles." Id. at 566 n.1. (1988).

50. Kuhlmeier v. Hazelwood School Dist., 795 F.2d 1368 (8th Cir. 1986), rev'd, 108 S. Ct. 562

51. Id. at 1372; see supra notes $27-30$ and accompanying text.

52. Hazelwood, 795 F.2d at 1375-76.

53. Hazelwood, $108 \mathrm{~S}$. Ct. at 567-69. The "public forum" concept has emerged only in the last few years as a significant but sometimes confusing issue in freedom of expression cases. Under this line of cases, the appropriate level of judicial scrutimy concerning speaker access to communication cliannels depends upon the nature of the forum to which the speaker seeks access. In such "traditional" public forums as streets and parks, or in a public forum created "by government designation," limitations on access "are subject to heightened scrutimy." Board of Airport Comm'rs v. Jews for Jesus, Inc., $107 \mathrm{~S}$. Ct. 2568, 2571 (1987). In a "nonpublic fornm," however, access "may be restricted by government regnlation as long as the regulation 'is reasonable and not an effort to suppress expression merely because [publicl officials oppose the speaker's view.' "Id. (quoting the leading nonpublic forum case, Perry Educ. Ass'n v. Perry Local Educators' Ass'n, 460 U.S. 37,46 (1983)) (word "public" appears in Perry but not in Jews for Jesus' quotation of Perry).

Applying this standard in Hazelwood, the Court found that a scliool is not a traditional public forum. Nor was the school newspaper in Hazelwood a designated public forum, because tlie administration of Hazelwood High liad not intentionally opened the paper to " 'indiscriminate use' by its student reporters and editors, or by the student body generally. Instead they 'reserve[d] the forum for its intended purpos[e]' as a supervised learning experience for journalism students." $108 \mathrm{~S}$. Ct. at 569 (quoting Perry, 460 U.S. at 46 (citations omitted)).

Justice White, who authored the majority opmions in both Hazelwood and Perry, has led the Court in applying the public forum concept in ways that incrcase institutional discretion over the claims of individual speakers seeking access to institutional communication channels. In Justice 
ing that educators have presumptive control over "school-sponsored publications, theatrical productions, and other expressive activities" whenever such activities are faculty-supervised and involve a school's educational mission in a way that implies school sponsorship. ${ }^{54}$ The Court thus read Fraser broadly as a case that turned not only on the vulgarity of the speech in question, but also on the school's sponsorship of the assembly in which the speech occurred. Students' first amendment rights will outweigh educators' decisions not when a speech lacks vulgarity, but "only when the [educator's] decision ... has no valid educational purpose." 55 By creating such a category of education-related speech, the opimion limits Tinker to "personal expression that happens to occur on the school premises." 56

When the Court applied the "valid educational purpose" standard to the Hazelwood facts, it required only a rational basis for the principal's actions. The Court found that the principal "could reasonably" have based some of his decisions on educational considerations, such as whether the student writers had mastered the journahsm class curriculum on the treatment of controversial issues, whether the student editorial decisions had satisfied journalistic standards, or whether the material was appropriate for Spectrum's high-school-age readers. ${ }^{57}$ Other decisions by the principal were common sense judgment calls, such as assessing the likelihood that the stories would offend the families they described and judging whetlier time allowed changes in the stories before the publication deadline. ${ }^{58}$

The Court's analysis suggests that the Hazelwood standard involves two stages of inquiry: courts must first ask whether the student expression at issue occurs in a context that implicates the school's educational mission and must tlien ask whetler the educator's decision lias a rational - but not necessarily an explicitly educational—basis. Satisfying the first requirement demands the presence of an education-related activity-an activity, in or out of the ciassroom, that is "supervised by faculty members and designed to impart particular knowledge or skills to stu-

White's view, organizations are free to define the scope of such channels (and thereby to limit speaker access) so long as that definitional process does not involve viewpoint discrimination and is "reasonable in light of the purpose which the forun at issue serves." Perry, 460 U.S. at 49. His analysis in Hazelwood is consistent with this general view.

54. Hazelwood, $108 \mathrm{~S}$. Ct. at 569-71.

55. Id. at 571 .

56. Id. at 569. By leaving Tinker intact to this extent, the Court preserved a higher level of judicial scrutiny for the protection of personal student expression than would apply if the "reasonableness" standard now governing access to nonpublic fornms applied to all student expression inside school premises. See supra note 53.

57. Hazelwood, $108 \mathrm{~S}$. Ct. at 572.

58. Id. 
dent participants and audiences,"59 or an activity that "students, parents, and members of the public might reasonably perceive to bear the imprimatur of the school." 60 The presence of such an activity removes the limited but real presumption favoring student speech under Tinker-a presumption that continues to apply to personal expression not mvolving educational activities-and creates at least some presumption favoring the school's discretion. This presumption requires a student who challenges an educator's decision within the educational sphere to prove that the decision lacked any reasonable basis.

This deference toward institutional discretion contrasts sharply with Tinker's requirement that a school restricting student expression make, if not a "coinpelling interest" showing, at least a strong affirmative showing of likely harin to school interests. ${ }^{61}$ By shifting the burden of proof to students, Hazelwood echoes the approach that Justice Harlan recommended in his Tinker dissent: "I would . . . cast upon those coinplaining the burden of showing that a particular school measure was motivated by other than legitimate school concerns ...."62

Hazelwood's analytical approach makes the case soinewhat analogous to New York v. Ferber, ${ }^{63}$ one of the Court's "rare modern case[s] in the tradition of the Chaplinsky exclusionary categorization approach" to free expression analysis. ${ }^{64}$ Just as Ferber placed the entire category of non-obscene child pornography beyond the range of traditional first amendment protection, Hazelwood characterizes the entire category of student expression within official educational channels or activities as speech entitled to only mimimal judicial protection. Much of the ambiguity created by Tinker arose because the Tinker Court failed to treat education-related speech in exphicitly categorical terms. Tinker did make

59. Id. at 570 .

60. Id. at 569.

61. Under Tinker, a school needed to demonstrate that a prohibition of student expression was "necessary to avoid material and substantial interference with school work or discipline." Tinker v. Des Moines Indep. Community School Dist., 393 U.S. 503, 511 (1969). The Tinker Court fortified this requirement by stating that "[i]n the absence of a specific showing of constitutionally valid reasons to regulate their speech, students are entitled to freedom of expression of their views." Id.

62. Id. at $\mathbf{5 2 6}$ (Harlan, J., dissenting). Applying this standard, Jnstice Harlan found "nothing in [the Tinker] record which impugns the good faith" of the school officials. Id.

63. 458 U.S. 747 (1982).

64. G. Gunther, Constitutional LAw 1096 (11th ed. 1985). Chaplinsky v. New Hampshire, 315 U.S. 568 (1942), the "fighting words" case, held that certain categories of speech are outside the limits of first amendment coverage. This approach, although narrowed in most respects, remains the basis for the Court's approach to obscenity, see Miller v. California, 413 U.S. 15 (1973), and child pornography, see New York v. Ferber, 458 U.S. 747 (1982). 
general allowance for the special environment of the school, ${ }^{65}$ but as most courts read it, Tinker required a fact-sensitive balancing approach in each case. That balancing process forced courts to weigh carefully such issues as the likelihood of disruption or harm, thus subjecting school discretion to a higher level of judicial scrutiny that left the presumption favoring student speech intact.

Hazelwood, in contrast, reverses this presumption by applying a deferential reasonableness standard once the context of the speech has satisfied the education-related definitional test. Unfortunately, the majority was not entirely consistent in explaining how that standard should be apphed. Although Justice White spoke generally of reasonableness, he defined the standard in this way: "It is only when the decision to censor . . . student expression has no valid educational purpose that the First Amendment" requires judicial intervention. ${ }^{66}$ Elsewhere he stated that a school's editorial control is justified "so long as [educators'] actions are reasonably related to legitimate pedagogical concerns."67 A hiteral apphcation of this.language could require an "educational"- not just a reasonable-justification for each decision that limits student expression, even if the decision occurs in colmection with a school-supervised activity. However, the larger context of Hazelwood suggests the appropriateness of a less deinanding rational basis standard.

Justice White, for example, consistently used a general reasonableness test in evaluating the decisions of Hazelwood High's principal, never asking whether any of those decisions had an exphicit educational purpose. The test did not require the principal to cite educational objectives to justify his concern about invading some students' privacy, his behef that the parents mentioned in the stories should have an opportunity to respond, his decision that time allowed no rewrites of the questionable stories, or his judgment that the paper's timely publication required pulling certain non-offending stories. ${ }^{68}$

Moreover, the Court's prior public forum cases liad already created a reasonableness standard for decisions denying adult speakers access to nonpublic forums, ${ }^{69}$ and the limited maturity of students ordinarily gives public schools greater discretion than other state agencies. The Court will uphold state decisions barring access to nonpublic forums if they are

65. "[T] $]$ he Court has repeatedly emphasized the need for affirming the comprehensive authority of the States and of school officials, consistent with fundamental constitutional safeguards, to prescribe and control conduct in the schools." Tinker, 393 U.S. at 507.

66. Hazelwood, $108 \mathrm{~S}$. Ct. at 571 (emphasis added).

67. Id.

68. Id. at 571-72.

69. See supra note 53. 
"reasonable in light of the purpose served by the forum."70 The Hazelwood majority underscored the relevance of the nonpublic forum cases by citing Perry Education Association v. Perry Local Educators' Association for the proposition that " $[s]$ chool officials were entitled to regulate the contents of Spectrum in any reasonable manner."71 Justice White added: "It is this standard [from Perry], rather than our decision im Tinker, that governs this case."72

Perry's requirement that himitations on access to nonpublic forums be "reasonable in liglit of the purpose served by the forum"73 suggests that the "educational" portion of the Hazelwood test primarily addresses the definitional question whetler the student expression occurs within a "school-sponsored expressive activit[y]."74 Thus, the requirement of "pedagogical" objectives or "valid educational purposes" mainly determines whether the Hazelwood standard apphes in the first imstance. Once it is established that the contested expression took place within a nonpublic forum that has an educational purpose, Hazelwood instructs courts to ask whether the restrictions are reasonable in liglit of that purpose-not whether the restrictions themselves have a particular educational purpose.

This deferential approach finds support in Justice White's wideranging rationale for regarding educational activity as a spliere requiring special treatment: "the education of the Nation's youth is primarily the responsibility of parents, teachers, and state and local scliool officials, and not of federal judges."75 The opinion gave three reasons why courts should defer to public school officials within the realm of educational activities: (1) to maximize the educational or "teacling" value of the activity, (2) to protect immature student audiences, and (3) to avoid erroneous attribution of school sponsorship. ${ }^{76}$ The first of these reasons (and,

70. Cornelius v. NAACP Legal Defense and Educ. Fund, Inc., 473 U.S. 788, 806 (1985).

Control over access to a nonpublic forum can be based on subject matter and speaker identity so long as the distinctions drawn are reasonablc in light of the purpose served by the forum and are viewpoint-neutral. . . .

....

... The Government's decision to restrict access to a nonpublic forum need only be reasonable; it need not be the most reasonable or the only reasonable limitation.

Id. at 806, 808 (emphasis in original); see also Perry Educ. Ass'n v. Perry Local Educators' Ass'n, 460 U.S. 37, 46 (1983) ("[T]he State may reserve [a nonpublic] forum for its intended purposes, communicative or otherwise, as long as the regulation on speech is reasonable and not an effort to suppress expression merely because public officials oppose the speaker's view.").

71. Hazelwood, 108 S. Ct. at 569 (emphasis added) (citing Perry, 460 U.S. at 46).

72. Id. at 569 .

73. See supra note 70.

74. Hazelwood, 108 S. Ct. at 571.

75. Id.

76. Id. at 570 . 
more remotely, the third) arguably applies to educational institutions at any level, but the second two especially concern the effect of institutional sponsorship on the teaching of social and other norms to public-schoolage children. ${ }^{77}$

Taken together, these three factors indicate the Court's concern witl strengthening the overall institutional authority of public scliools in recognition of the compelling need to educate the nation's children more successfully, both in academic skills and in citizenship. Deferring to school officials within a broadly defined educational context may seem to have a chilling effect on student expression, but too much deference to student expression can liave an equally chilling effect on the exercise of authority that successful education frequently requires. On balance, even an empliasis on students' first amendment interests calls for a general choice favoring the best educational outcome.

Hazelwood ecloes the Court's highly deferential treatment of institutional academic freedom in Regents of the University of Michigan $v$. Ewing, which upheld a faculty committee's judgnient of a university student's unfitness for continued enrollment. ${ }^{78}$ The Court in Ewing would not override "the faculty's professional judgnient" unless it was "such a substantial departure from accepted academic norms as to demonstrate that the person or committee responsible did not actually exercise professional judgment."79 Observing that "considerations of profound importance counsel restrained judicial review of the substance of academic decisions," Justice Stevens's majority opinion emphasized the judiciary's unsuitability to "evaluate the substance of the multitude of acadennic decisions that are made daily by faculty members of public educational institutions." 80 The institutional academic freedom stressed in Ewing serves not only the need for an orderly school environment (with which Tinker seemed principally concerned), but, more affirmatively, serves students' and society's interests in maintaining the first ainendment's educational values.

77. See supra note 25 and accompanying text. The Court expressly declined to decide whether its treatment of school-sponsored activities applied to colleges and universities, Hazelwood, $108 \mathrm{~S}$. Ct. at 571 n.7, but it did not foreclose that possibility. The Court did regard the new Hazelwood standard as consistent with the broad protection given to private student speech on a university campus in Papish v. Board of Curators, 410 U.S. 667 (1973) (per curiam), "which involved an offcampus 'underground' newspaper that school officials merely had allowed to be sold on a state university campus." Hazelwood, 108 S. Ct. at 570 n.3 (citing Papish). Moreover, to the extent that Hazelwood rests on the idea that a school is not a traditional public forum, institutions of higher education could arguably regulate the content of and access to their official publications by not designating them as public forums. See supra note 53.

78. 474 U.S. 214 (1985); see supra notes 14-16 and accompanying text.

79. 474 U.S. at 225.

80. Id. at 226. 
One could, of course, view Hazelwood more narrowly and conclude that the Court merely decided that a high school principal's ultimate legal responsibility makes her the "publisher" of a school-financed paper. By analogy to the organization of its real-world counterparts, the school newspaper staff must respect the routme administrative hierarchy that leaves ultimate publication decisions with the publisher, the paper's chief executive officer. That analogy alone would have justified reversing the Eiglitli Circuit's holding in Hazelwood - that the principal could not imterfere with student publication decisions without slowing that the decision would create substantial disorder or subject the scliool to tort liability. ${ }^{81}$

Yet tlie publisher analogy provides more than an organizational coinparison. A newspaper, typically a private corporate entity headed by its publisher, enjoys first amendment protection institutionally. Its reporters have their own constitutional rights of expression, but only against the state-not against the newspaper, which is not a state actor. ${ }^{82}$

Whom, then, does the first amendment protect in a public scliool, and against what forms of intrusion? Because we typically think about rights of expression ouly in individual terins, and because a school is technically an agency of the state, the school as an institution-or the principal representing tle institution-may not seem a proper candidate for constitutional protection. For example, courts such as the Eiglitl1 Circuit assuine that the school newspaper enterprise implicates only students' rights of expression.

The root question, which the typical first amendment model fails to address, is how to organize and operate schools in order to maximize their overall contribution to the values and purposes of the first amendment. ${ }^{83}$ Hazelwood regards that issue as a matter of educational policy, not constitutional law; therefore, it gives presumptive responsibility for such inquiries to the educational system rather than the judiciary. Thus,

81. Kuhlmeier v. Hazelwood School Dist., 795 F.2d 1368, 1375-76 (8th Cir. 1986), rev'd, 108 S. Ct. 562 (1988).

82. However, a friend who is the publisher of a regional newspaper recently told me that his "cub reporters," reflecting the individual rights assumptions that influence popular views of the first amendment, occasionally object to what they perceive as "censorship" by the paper's editorial staff, calling such supervision a violation of their free speech rights.

83. The typical first amendment model assumes a confict between individuals and the state, and our preference for protecting the individual's expression will generally resolve such conflicts against the state. Yet to protect their prerogatives witlin the school's institutional structure, most faculty and administrative personnel could arguably invoke their right to freedom of expression against other school personnel. The parties on both sides of many such disputes would teclunically be state agents. In such circumstances, the standard first amendment model does not help a court to identify the school officials whose authority will best protect tlie academic and expressive interests that serve first amendment values. 
the school's principal and faculty supervise all educational activities to ensure that their school will educate successfully, and not merely because they are "publishers." In that sense, the institution of a school, like that of a newspaper corporation, is protected by the first amendment. The first amendment's interest in promoting sound educational poticies protects schools from second-guessing by the courts when educational issues are at stake. As part III explores, this basic stance advances rather than obstructs the achievement of the goals of our system of free expression.

\section{SCHOOLS AS FIRST AMENDMENT INSTITUTIONS}

It has been argued persuasively ${ }^{84}$ that first amendment theory should act primarily to limit the exercise of schools' discretion, in order to protect children agamst the risks of indoctrination and to teach them the value of participatory democracy and personal autonomy. This approach would also enable them to learn both hiterally and symbolically that the purpose of the Bill of Rights is to limit state authority.

However, judicial intervention intended to limit abuses of discretion by educators does not necessarily lead to a policy of unbounded free choice for students, who may need protection against the harmful consequences of their own decisions as much as protection against abuses by school personnel. That fact about children hes at the base of our legal system's concept of minority status.

Arguments that stress students' rights of expression also presuppose that children have the rational capacity necessary for meaningful participation in the political process and the marketplace of ideas. But because "a child . . . is not possessed of that full capacity for individual choice which is the presupposition of First Amendment guarantees,"85 children do not enjoy the most fundamental of democratic rights, the right to vote. Moreover, because children lack the capacity to evaluate the meaning of apparent state sponsorship, the establishment clause forbids public prayer in schools-even while it permits public prayer in a legislative chamber. ${ }^{86}$ The Hazelwood dissenters overlooked the mature capacity

84. See, e.g., Hazelwood, 108 S. Ct. at 573-75 (Brennan, J., dissenting); Levin, Educating Youth for Citizenship: The Conflict Between Authority and Individual Rights in the Public School, 95 YALE L.J. 1647, 1662-67 (1986); van Geel, The Search for the Constitutional Limits on Government Authority to Inculcate Youth, 62 TEx. L. REv. 197, 237 (1983).

85. Tinker v. Des Moines Indep. Community School Dist., 393 U.S. 503, 515 (1969) (Stewart, J., concurring) (quoting Ginsberg v. New York, 390 U.S. 629, 649-50 (1968)); accord J. MILL, ON LIBERTY 13 (C. Shields ed. 1956) ("It is, perhaps, hardly necessary to say that [the marketplace of ideas] doctrine is meant to apply only to human beings in the maturity of their faculties. We are not speaking of children . . . "); see also sources cited in Hafen, supra note 5, at 702-09.

86. Compare Wallace v. Jaffree, 472 U.S. 38 (1985) (state statute authorizing period of silence in public schools for meditation or silent prayer violates establishment clause) with Marsh v. Cham- 
issue, arguing instead that a published disclaimer of official sponsorship could overcome the majority's fears about erroneous attribution of school sponsorship to ideas expressed im a school newspaper. ${ }^{87}$ Query whether a similar public disclaimer before a group classroom prayer would overcome any appearance of school endorsement. ${ }^{88}$

Beyond the difficulties created by children's lack of mature capacity, the idea that the first amendment exists only to constrain state or mstitutional action overlooks (and indeed interferes witli) the affirmative contributions that scliools and other institutions can inake im fulfilling the amendment's purposes. A child's most fundamental imterest im first amendment values may be im developing the capacity for self-expression and the capacity to enjoy meaningful personal autonoiny. " [F]reedom of expression' lias two meanings: (1) freedoin from restraints on expression and (2) freedom for expression-that is, liaving the capacity for selfexpression." 89 Until clildren liave developed this freedoin "for expression," their freedom "from restramts on expression" lias only limited value. Thus, a child's "right" to an effective education directly involves both the personal and social interests that underlie the first amendment.

Even accepting the need for effective education, children arguably will best develop their faculties if they are protected against adult authority. That was a major premise of the 1960 s reform era, a period symbolized by anti-authoritarian protests on college campuses and by popular childhood education theories that challenged the need for adult authority. ${ }^{90}$ One well-known theory, for example, began with the view that a child is "innately wise and realistic. If left to himself without adult suggestion of any kind, lie will develop as far as he is capable of developing."91 Empirical evidence accuinulated since the reform era, however, forcefully denonstrates that the widespread reduction of institutional authority in public scliools over the past generation is statistically correlated with the recently publicized declines in the acadennic aclievement of American students. Indeed, inost studies assessing that period agree: "You don't replace soinething with notling. Of course, that was exactly

bers, 463 U.S. 783 (1983) (state legislature's practice of opening each session with prayer led by state-paid chaplain does not violate establishment clause).

87. Hazelwood, $108 \mathrm{~S}$. Ct. at 579 (Brennan, J., dissenting).

88. See Stone v. Graham, 449 U.S. 39 (1980), which held that the establishment clause was violated when copies of the Ten Commandments were placed on the walls of public classrooms in Kentucky, even though the posted copies contained "[i]n small print below the last commandment" a notation indicating that the "secular application of the Ten Commandments is clearly seen in its adoption as the fundamental legal code of Western Civilization and the Common Law of the United States." Id. at $39 \&$ n.1.

89. Hafen, supra note 5, at 666 (emphasis in original).

90. Id. at 677-81.

91. A. Neill, Summerhill: A Radical Approach to Child Rearing 4 (1960). 
what the educational reform of the sixties was doing."92

Whatever one makes of this evidence, the question whether authoritarian or anti-authoritarian approaches will best develop the minds and expressive powers of children is more a matter of educational philosophy and practice than of constitutional law. For that reason alone, first amendment theories applied by courts largely on the basis of anti-authoritarian assumptions are at best a clumsy and limited means of ensuring optimal educational development, whether the goal is an understanding of deinocratic values or a mastery of basic intellectual skills. Thus, one of Hazelwood's major contributions is its reaffirmation of schools' institutional role-and their accountability to the public for fulfilling it responsibly-in nurturing the underlying values of the first amendment.

A school is not just another bureaucratic ann of the state, but is an institution that mediates between the individual and the megastructures of contemporary government. Partly because of this function, parental influence over and local control of the schools have been major theines in the nation's educational history. ${ }^{93}$ From this vantage point, the schools' prinary purpose is to contribute affirmatively to the development of the American system of free expression. To achieve that goal, schools must interact with students in ways unique among all forms of interaction between the state and individuals: supervising, directing, forbearing, all according to personalized educational judgments about the needs and circunstances of each child.

In Hazelwood, the Suprene Court recognized the schools' distinctive institutional role as a potential source of support for, not always interference with, first amendment values. To gain a sense of the historic significance of this developinent, consider soine of the origims of the assumption that first ainendinent protections are prinarily a inatter of individual rights.

The highly visible individualism of the past twenty or thirty years is but a noisy extension of such slow-moving but definite historical currents as the movement from group-oriented status to individual-oriented contract ${ }^{94}$ and the concept of "history as the decline of coininunity."95 Thus, individuatistic assumptions regarding first amendinent interests

92. A. Bloom, The Closing of The American Mind 320 (1987). For summaries of research reported by James Coleman, Gerald Grant, and Diane Ravitch, among others, as well as the recommendations of such groups as the National Commission on Excellence in Education (which authored $A$ Nation at Risk), see Hafen, supra note 5, at 677-95.

93. See generally Hafen, supra note 5 (developing theme of public schools as mediating structures).

94. See H. Maine, ANcient Law 163-65 (F. Pollock ed. 1963) (relations between persons no longer defined by family but by free agreement among individuals).

95. See R. Nisbet, The QUeST FOR CoMmunitY 75-98 (1953). 
have direct antecedents in Western history. The Reformation led by Martin Luther was, at its theological as well as its political core, a rejection of institutional religious authority. Even more significantly for our American assumptions about the ineaning of "religion" in the first amendinent, the dominant Protestant consciousness of our founding era einphasized a direct, two-way relationship between the individual and God, as opposed to the emphasis on institutional and community autliority in the Catholic and Jewish traditions. ${ }^{96}$ In addition, the notion of acadenic freedoin had an individualistic flavor when imported froin Gerinany in the late nineteenth and early twentietl centuries, especially in its American version, which stressed the interest of individual faculty meinbers in "protecting [their] acadermic job[s]" against intrusion by lay boards of trustees. ${ }^{97}$ Constitutional protection for academic freedoin also developed as an individual matter; the Court applied the political speech theories that grew out of the 1950s anticominunism cases to the early acadenic freedom cases..$^{98}$

Institutional interests hardly necded emphasis in first amendinent theory when these developinents were taking place. Despite the slowly growing intellectual force of the individualistic theories, longstanding and customary patterns of institutional autlority dictated an attitude of judicial deference toward establislied institutions until well past 1950. Indeed, the Supreme Court hardly took an interest in freedom of speech as an individual right until World War I, and from that time until the 1960 s, the gradually developing protection for individual expression simply chipped away at the pro-institutional status quo. ${ }^{99}$

96. The influence of Protestant conceptions in Western civilization shifted the focus in religion from the visible to the invisible church: "the individual inan of faith replaced the corporate Church as the repository of divine guidance." Id. at 243; see Tushnet, The Constitution of Religion, 18 CONN. L. REV. 701, 731 (1986).

97. R. Hofstadter \& W. Metzger, The Development of ACademic Freedom in the UNITED STATES 398 (1955). In fact, however, it was the institutional academic freedom of the nineteenth-century German universities that vitalized the concept of a university as a place defined primarily as a community of free inquiry. Institutional leaders of these universities were elected by their faculty colleagues, not appointed by lay trustees, as was the typical case in America. This difference accounts for inuch of the incrcased einphasis on the individual faculty inember advocated by such organizations as the American Association of University Professors in the early 1900s. Id. at $396-400$.

98. See, e.g., Keyishian v. Board of Regents, 385 U.S. 589 (1967) (state plan designed to remove "subversive" employees violated first amendment); Swcezy v. New Hampshire, 354 U.S. 234 (1957) (contempt conviction of college professors for refusal to answer questions concerning content of lectures violated academic freedom and right to political expression).

99. The historical development of academic freedom in the United States after 1900 illustrates this pattern. Note the progression of the essays in The Constitutional STatus of ACADEMIC FREEDOM (W. Metzger ed. 1977). 
During the 1960s and 1970s, however, the traditional hegemony of institutions declined dramatically, and the pendulum of constitutional history swung away from the relatively uncritical assumptions favoring institutional authority toward powerfully articulated individual protections. It could have been predicted that this pendulum would at soine point hit the mdividualistic extreme and reverse course. During the last few years we have begun to sense the limits of unrestrained individualism and its toll on community and institutional continuity, especially with respect to mediating institutions.

Contemporary studies report Americans' deep concern "that this imdividualism may have grown cancerous," and may be undermining the mfluence of such mstitutions as family, church, and local community im ways that threaten "the survival of freedom itself." 100 Similarly, a thoughtful comparison of American and European approaches to the reform of abortion and divorce laws ${ }^{101}$ finds that, despite some basic common assumptions, the American approach has become so mdividualistic and unbalanced that it has severed the connections between personal values and social values that European approaches have retained. ${ }^{102}$

In 1830, Alexis de Tocqueville foresaw the risks of democracy's tendency to encourage an acquisitive and destructive individualism, but he also believed that the commitment of Americans to mediating institutions would "combat the effects of individualism by free institutions." 103 Thus, for Tocqueville, the "intellectual and moral associations" in American life-of which the local school is a classic exainple-were so important that "[n]othing ... more deserves attention."104 Closer to our own time, Robert Nisbet echoed Tocqueville's theme with his argument that the institutional strength of mediating structures provides a crucial protection against totahtarianism. The totalitarian cannot succeed until "the social contexts of privacy-family, church, association-have been atonnized. The political enslavement of man requires the emancipation of man from all the [imtermediate] authorities and memberships ... that

100. R. Bellah, R. Madsen, W. Sullivan, A. Swidler \& S. Tipton, Habits of the HEART vii (1985).

101. M. Glendon, Abortion ANd Divorce in Western LaW (1987).

102. Continental legal systems

have imagined the human person as a free, self-determining individual, but also as a being defined in part through his relations with others. The individual is envisioned, inore than in our legal system, as situated within family and community; rights are viewed as inseparable from corresponding responsibilities; and ... [p]ersonal values are regarded as higher than social values, but as rooted in them.

Id. at 133.

103. A. De Tocquevilie, Democracy IN America 509 (J. Mayer ed. 1966).

104. Id. at 517. 
serve . . . to insulate the individual from external political power."105 Nisbet warned that reducing the authority of mediating institutions creates exactly the kind of "spiritual and cultural vacuum" that "the totahtarian must have for the realization of his design."106

American public schools were originally established as an extension of the private, local, mediating sphere, receiving from parents a delegation of authority to teach not only intellectual matters, but also the skills and values that allow individuals to resist domination by the state. That was the Jeffersonian ideal. In more modern times, the place of public schools in our cultural and political structure has become less clear, perhaps in part because the schools were called upon to perform a leading role in fulfilling the urgent need to desegregate American society. One unintended consequence of requiring schools to serve as pohtical agents of the state may be that their normal institutional authority can appear to threaten individual liberties in the same way that any potent governmental bureaucracy does. Partly for this reason, the role of public schools today can be a source of tension and confusion, erupting in conflicts between parents and schools, local cominumities and state governments, state interests and federal interests, and individuals and the state.

The Hazelwood case reminds us, however, that the idea of in loco parentis as an educational premise is not only not dead, but can become a needed means of protectimg the right of children to develop their capacity for meaningful expression-if the schools in fact respond to this constructive reinforcement of their authority. It is as though the Court needed the perspective furmished by a time of excessive individuahism to see that first amendment institutions such as schools and churches are not always an impediment to mdividual rights, but can be a vital means of fostering long-term personal hiberty: "Sohicitude for a church's [or a school's] ability to [engage in its own self-definition] reflects the idea that furtherance of the autonomy of rehioious [or educational] organizations often furthers individual rehgious [and other first amendment] freedom[s] as well."107

The first amendment embodies values that are the carriers of meaning for individuals and the sources of social and political contimuity for society. Those values can and should guard the imstitutional interests that sustain and nurture individual development. The first amendment must therefore protect not only individual writers, but newspapers; not only religious persons, but churches; not only mdividual students and

105. R. NISBET, supra note 95 , at 202.

106. Id. at 203.

107. Corporation of the Presiding Bishop v. Amos, 107 S. Ct. 2862, 2871-72 (1987) (Brennan, J., concurring). 
teachers, but schools. These "intellectual and moral associations" form a crucial part of the constitutional structure, for they help teach the peculiar and sometimes paradoxical blend of liberty and duty that sustains both individual freedom and the entire culture from one generation to the next. 